\title{
INSTITUTIONAL ISOMORPHISM AND THE PERSISTENCE OF THE PRESENT INTERNATIONAL ORDER
}

\section{Vítor Ramon Fernandes}

vitor.fernandes60@gmail.com

Assistant Professor at the Lusíada University (Portugal) and Visiting Scholar at the University of Cambridge (Wolfson College and, previously, at the Department of Politics and International Studies)

\begin{abstract}
International orders reflect the settled arrangements that define relations between states in certain moments in history. Order breaks down when the adopted set of organizational principles that define roles and the terms of those relations cease to operate. International organizations are a central feature of the current order and an important source of legitimacy. This article extracts a set of ideas derived from the new sociological institutionalism literature in organizational analysis and sets out an argument showing their possible implications for the present order. I argue that there are certain organizational features related to institutional isomorphism that may well support the persistence and maintenance of the current international order. The argument is based on the homogeneity of practices and arrangements found in different institutions and organizations. The persistence of those practices and their reproduction in structures are to some extent self-sustaining and may provide additional support to the idea that the current American-led international order may last longer than is often thought while allowing for changes in the distribution of power.
\end{abstract}

\section{Keywords}

International Organization; New Institutionalism; Institutional Isomorphism; Organizational Field; International Order

\section{How to cite this article}

Fernandes, Vítor Ramon (2019). "Institutional isomorphism and the persistence of the present international order". JANUS.NET e-journal of International Relations, Vol. 10, N.0 1, MayOctober 2019. Consulted [online] on the date of the last visit, https://doi.org/10.26619/1647$\underline{7251.10 .1 .1}$

Article received on May 27, 2018 and accepted for publication on February 02, 2019

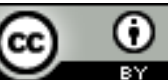




\title{
INSTITUTIONAL ISOMORPHISM AND THE PERSISTENCE OF THE PRESENT INTERNATIONAL ORDER
}

\author{
Vítor Ramon Fernandes
}

\section{Introduction}

The current international order ${ }^{1}$ is considered to be changing. There are power shifts taking place and the question regarding the nature of that change is a crucial one. Critically, it matters whether the power transitions that are taking place will lead to a bipolar order, or even to a multipolar one. But, in addition, it will be important to see whether there will be major changes in the operating nature of that order, or whether it will retain many of its main features, namely with respect to the role and importance of international organizations. ${ }^{2}$

Taking stock of the importance that international organizations and other institutions have had in the creation and maintenance of the current international order, the main argument presented here is that there is also a set of ideas that arises from sociology that may help sustain it. There are a number of organizational features pertaining to organizational theory related to institutional isomorphism, in particular, that should be drawn attention to given that they are likely to have an important influence regarding the way that international organizations operate and which, as a result, may provide significant support to the persistence of the current international order. These ideas follow from work related to the new institutionalism ${ }^{3}$ in organization theory and sociology - the new sociological institutionalism.

This approach rejects rational-actor models and considers institutions as independent variables in alternative to the more conventional approaches that take institutions as the consequence of motives and actions based simply on rational behaviour (Powell and DiMaggio, 1991). The new sociological institutionalism is the most influential theory in recent decades that studies matters related to institutional development. It is based on

1 International order is considered to be the set of norms, rules and arrangement between states that guide the interactions between them, and, in particular, how major powers interact between them and with other states (see, for example, Ikenberry, 2001, 2014).

2 International organizations are defined here, essentially, as organizations that have representatives from three or more states supporting a permanent secretariat and that are assigned to perform certain tasks in order to achieve certain defined and common objectives. Defined in this sense, it only encompasses international governmental organizations. However, although the focus of the analysis is centred on those, much of what is argued here in this article also applies to other international organizations, namely, nongovernmental organizations. On this matter, see for instance, Archer (2014).

3 As noted by Powell and DiMaggio (1991: 1): "there are many 'new institutionalisms'". Here, I will be concerned with the New Institutionalism in organizational studies and sociology. Its characteristics will become clearer as I proceed. 
arguments that differ quite significantly from the more common line of research concerning the role and importance of international organizations, most notably in the creation and maintenance of the current international order within liberal institutional theory and regime theory. It is, nevertheless, complementary to it.

The remainder of the article unfolds as follows: In the first section, I present a brief analysis of the current international order with a view to characterizing the overall context of the main argument. Here, in addition to a number of general considerations about the nature and stability of the present order - while also contextualizing some of the power shifts that are taking place, most notably with the rise of China - I review the importance that international organizations have had in that order until now. The second section lays out a number of considerations on the nature of international organizations, drawing attention to their organizing principles and elements as bureaucracies. Here, I point out some of the most important features of international organizations as bureaucracies from an organizational theory viewpoint in order to highlight their importance and relevance in international politics. In this section, I also discuss the importance of power in the context of international organizations. In the next section, I illustrate some of the most well-known approaches that can be applied when studying organizations, in order to contextalize the perspective that I will follow in presenting my main argument. Some of the differences between these perspectives are also highlighted. The following section presents the main arguments on institutional isomorphism based on the work of Meyer and Rowan (1977), and DiMaggio and Powell (1983), given that they are essential to the main argument. After that, I argue that the mechanisms identified as sources of isomorphism, and indeed of some homogenization resulting from institutional isomorphism, are likely to play an important role in the maintenance of the current international order. The article ends with a conclusion of the main arguments.

\section{The enduring stability of the current international order}

A great deal has been written in the international relations literature about the role of international organizations and other institutions in the present international order, most notably, how they have been an essential part of the current order since the end of World War II. One very important attribute has been to provide collective legitimacy. The latter is very important, given that "Legitimacy is a property of a rule or rulemaking institution which itself exerts a pull toward compliance on those addressed normatively because those addressed believe that the rule or institutions has come into being and operates in accordance with generally accepted principles of right process" (Franck, 1990: 24). International orders reflect the settled arrangements that define relations between states in certain moments in history. Order breaks down when the adopted set of organizational principles that define roles and the terms of those relations cease to operate. Agreedupon rules and institutions limit state power, and international organizations are a central feature of the current order as well as an important source of legitimacy (Ikenberry, 1998/99, 2001, 2014).

Since the collapse of the Soviet Union, the United States has enjoyed unparalleled power in the international system, with a level of power preponderance that no other state has matched in modern history. For that reason, this order is characterized as unipolar. Time will tell if, and when, we will return to a different kind of order, bipolar, as was the case during the cold war or to a multipolar one as many predicted would occur soon after the 
end of the Soviet Union. However, so far this has not happened. It does, however, seem likely that the United States and China will continue to be the two greatest powers in the international system in the coming decades as China's economy continues to grow at a fast pace, possibly even surpassing the United States on a number of fronts and despite still lagging very significantly in terms of military power. ${ }^{4}$

It will be crucial to watch how the relationship between these two countries, notwithstanding others, will unfold. Largely, it will also be about the relashionship between China and the liberal Western order that emerged after World War II through the leadership of the Unites States (Ikenberry, 2013). China still seems quite far away from becoming the first power, or superpower, in the world. ${ }^{5}$ It does not seem to wish to lead the world in a missionary way either. Nevertheless, China will want to push its interests forward and that will probably mean that world power will be shared between the United States and China at some point in time. In this context, there is a possibility that these countries succeed in finding ways to manage their differences and will be able to develop the prospects for political, economic and security cooperation leading to peace and stability in the international system. Furthermore, while China will likely want to reform parts of the postwar international rules-based order overtime in order to better suit its interest, this may occur without major changes in the way it operates.

Nevertheless, the possibility of conflict in the future exists if rivalries are not contained. The diplomacy of Beijing has sometimes been considered challenging, somewhat disturbing and often disrupting on several occasions (Christensen, 2011; Shambaugh, 2011). There is also some scepticism on what concerns the relationship between powerful states and international organizations. In addition, powerful states also often bend many of the international organizations norms to their will. Notwithstanding, membership of these organizations and adherence to the norms that they embody can be used as a way to demonstrate power and gain advantage. China will continue to try to limit and set boundaries on the United States power and international organizations can be effective institutions for that purpose.

All said, this order has also been relatively stable despite some significant shifts in the global distribution of power that seem hard to deny and are still taking place. ${ }^{6}$ This stability seems due to a number of institutional factors, namely, a number of "constitutional characteristics" (Ikenberry, winter 1998/1999: 45) that mitigate the existing differences in power between states and their implications, thereby reducing the need for states to balance. With its rules and norms, institutions are therefore a major component of the international order, exhibiting what Ikenberry (winter 1998/1999: 46) calls "increasing returns" characteristics. That may be considered relevant in the sense that the more they become a part of the present international order, the more they help maintain it and make it more difficult to overturn it. Furthermore, the current liberal international order can be organized in different ways. It has evolved over time and can

4 Military power is a crucial element here, notably in terms of polarity. The considerable difference still existing between the United States and China on this front is, from my perspective, considered essential for characterizing the international system as unipolar.

5 It remains to be seen if it ever will.

6 As one anonymous referee pointed out to me, examples such as the creation of the Asian Infrastructure Investment Bank - that is somewhat considered as a competitor of the World Bank - can be seen as resulting from the inability of the latter to allow changes in the distribution of power. My argument differs in the sense that I regard that situation as one possible circumstance of adjustment within the international order to allow for changes in the distribution of power and maintain its main features and characteristics. See also footnote 12 below. 
continue to evolve (Ikenberry, 2009). It can be more or less tied to the existing norms and institutions, it can be more or less open, and more or less rule-based or institutionalized.

\section{The nature of international organizations}

Irrespective of the issue that one considers in world politics, being it conflict, economic or financial matters, humanitarian issues, environmental concerns, or any other, one is bound to find international organizations involved. Their function is much more than just executing international agreements between states. They shape the global international order and, particularly since World War II, they are central to order building and its maintenance. They often make authoritative decisions that have global reach. In many situations, international organizations act as facilitators of policy coordination, as mechanisms for managing and legitimizing the solutions to problems that managed otherwise by independent states in an interdependent world, would simply remain unsolved.

In essence, international organizations are bureaucracies, which continue to be the privileged framework for organizing work in a complex world (Weber, 1947; Weber, Roth and Wittich, 1978). Bureaucracies are considered to be the most efficient system of organization and the most effective way to rationalize processes in the current world, given some of the features that are associated with it, namely spheres of competence defined within a division of labour with some form of hierarchy. In addition, the necessary work and the pursuit of the defined objectives are carried out according to rules and operating procedures, and irrespective of the people working there in a particular moment, that is, they are impersonal. They allow an organization to respond more effectively and predictably to demands. As such, bureaucracies are sets of rules that define complex social tasks within a certain division of labour in the pursuit of certain objectives.

Bureaucracies also affect the behaviour of others actors within the international system, such as countries and other bureaucracies (Krasner, 1983; Keohane, 1984). They also define and create rules that have an impact on the social world. Such an example would be the case of the International Monetary Fund (IMF), in the sense of creating rules for managing balance-of-payments problems, or activities in the sense of institutionalized procedures for solving specific problems or accomplishing certain tasks. Not least important, bureaucratic culture tends to guide action, although it does not determine it, in the sense that bureaucrats tend to share a similar view of the world because those bureaucracies influence their interests and shape their views (Campbell, 1998; Immergut, 1987; Swidler, 1986).

Another crucial theme related to international organizations is power. ${ }^{7}$ Much can be said about power and international organizations and, in that respect, it is important to distinguish power in international organizations from the power of those organizations. More specifically, one can think of power within organizations in the sense of the capacity and the ability that members of those organizations have in the creation and functioning of those organizations. The same can be said in terms of negotiating ability and agendasetting capability. However, here I wish to focus on the power of organizations. That is,

7 For a good discussion on power and international organizations see, for instance, Barkin (2013). 
the idea that these international organizations have independent power and one that is non-military. That power can also be expressed in terms of influence within those organizations, namely through agenda setting and the creation of procedures. An example would be the United Nations, concerning international peace and security. This power arises from moral authority, which provides the specific organization with legitimacy to act in a depoliticized manner and from an imparcial standpoint. However, it can also be used to push forward certain particular political positions and agendas.

The other source of power in international organizations is the production and control of information. Often, this authoritative power is related to the ability to make use of "epistemic communities" (Haas, 1992: 3), which allows organizations to present themselves as depoliticized and to emphasize an objective point of view with regard to knowledge. Again, a good example of this would be the IMF with respect to some claim regarding monetary policy prescriptions, but many other organizations can also provide similar examples. It is because bureaucrats possess information that others do not or, alternatively, because they can influence what information other actors should collect and reveal that they can increase their control over outcomes. In addition, bureaucratic power can include the ability to transform information into knowledge, giving it meaning, which can also have an effect in shaping social reality. All this provides a way of establishing rules and norms that international organizations wish to spread as models of good and adequate behaviour (Finnemore, 1996; Katzenstein, 1996; Legro, 1997). One of the functions of international organizations is considered to be the creation, spreading and enforcement of values and norms that are supposed to define what constitutes the acceptable and legitimate state behaviour.

\section{Different approaches to study international organizations}

Traditionally, international organizations have been studied from an institutional perspective (Kratochwil and Ruggie, 1986). From this perspective, which is a static one and does not allow understanding many of the changes that occur in these institutions, the way to proceed is generally through the study of their formal structures, organizing principles and hierarchies, which enables understanding what a specific organization can and cannot do. For instance, it would be impossible to understand the actions and politics of the United Nations without knowing how the veto power of the five permanent members of the Security Council works. The same can be said for the lending procedures of the IMF or the World Bank without being familiar with voting procedures. In addition, it is important to take into consideration that these organizations have both administrative employees and political appointees. A key distinction should be made here, given that the primary loyalty of the former is towards the organization and its goals whereas the primary loyalty of the latter is towards their respective governments. This has important implications for international governmental organizations.

Funcionalist and neofunctionalist approaches attempt to deal with the fact that international organizations change and evolve over time as new demands appear and become more international fuelled by increased cooperation. The difference between the former and the latter is that the latter also attempts to account for political demands and integration processes in addition to technical ones (Barkin, 2013: 29-40). Some funcionalist perspectives consider that international organizations exist due to the functions they perform, in the sense that states create them to try and overcome 


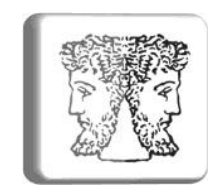

problems and difficulties that otherwise would not be possible, or simply too costly. Their attention tends to focus on issues related to transaction costs, incomplete information and other barriers that states try to overcome, but, in essence, they do not account for a more independent role by international organizations, one that allows the creation of independent agendas.

Notwithstanding, it is worth noting that funcionalist analysis also leaves open other important dimensions that have become increasingly important over the recent years, and particularly in the current international environment and with the current U.S. administration. Most notably, a number of international organizations, such as the United Nations, the World Trade Organization, and the UNESCO, among others, have become a battleground for states to operate in order to safeguard their interests within world politics, reflecting the power shifts that are occurring. ${ }^{8}$ Although there is a risk of this situation endangering the maintenance of the current international order in time, particularly if it persists, it does not undermine the correctness of my main argument.

The predominant approach for analysing international organizations in the international politics' realm is, in all probability, regime analysis. ${ }^{9}$ According to this approach, international organizations are considered to be formal structures that "can be defined as sets of implicit or explicit principles, norms, rules, and decision-making procedures around which actors' expectations converge in a given area of international relations" (Krasner, 1983: 2). As such, they also often lead to the creation of institutions, and some of which are international organizations that promote cooperation (Krasner, 1983; Keohane, 1984; Young, 1982, 1986). Some authors even argue that a regime always exists when there is a regular pattern of behaviour that is sustainable for a significant length of time (Puchala and Hopkins, 1982). In this sense, regimes and behaviour are closely linked. In turn, this may help maintain the current order. However, a crucial idea in this approach is that international organizations have no agency. Their role is the usual image of international organizations seen as instruments that states use to achieve their own goals (Archer, 2014: 117).

Significantly, and differently from what is generally considered in regime theory, several international relations authors, some of whom with a constructivist leaning, have disputed the value of the rational actor's approach to the study of institutions. They tend to adopt a more process-oriented perspective, whereby institutions constitute actors (states) but also constrain them, and which leads policy-makers to take into consideration norms and rules in their decision-making processes (Ruggie, 1982; Kratochwil and Ruggie, 1986; Krasner 1988; Keohane, 1988). From their perspective, international organizations promote norm dissemination because of the focus on trying to generate consensus through multilateralism. According to Acharya (2006: 113) "Without multilateralism, the norms of sovereignty would not have become so prominent a feature of the post-war international order". Operating according to international norms leads to norm dissemination, where a norm can be identified as "a standard of appropriate behaviour for actors with a given identity" (Finnemore and Sikkink, 1998: 891). Furthermore, it facilitates domestic approval for action like "international rules and norms can affect national policy choices by operating through the domestic political process (Cortell and Davis, 1996: 471). Moreover, norms matter and they have a real

\footnotetext{
I am grateful to one of the anonymous referees for pointing this out to me.

International regimes are generally considered to be multilateral agreements based on the notion that international cooperation is possible and occurs.
} 
and relevant impact on the way states behave. This occurs either through 'regulative' effets, in the sense that they induce states to behave in a certain way, or in a 'constitutive' way, which means that they influence the preferences and interests of states (Glanville, 2016: 186-187). Others argue that under certain restrictive conditions of the failure of individual actions by states to secure Pareto-optimal outcomes, international regimes may play an important role in the international system, despite its anarchic nature (Stein, 1982; Jervis, 1982).

Notwithstanding the relevance of the different approaches to organizational analysis, the focus here takes a different perspective, most notably from what is generally considered in the positive theory of institutions in general. The argument here is more of a sociological nature and does not necessarily follow a rational approach perspective. ${ }^{10}$ It is based on the new institutionalism literature in organizational analysis that considers the homogeneity of practices and arrangements found in different institutions and organizations. The persistence of those practices and their reproduction in structures are, to a certain extent, self-sustaining. Nevertheless, most significantly, it also allows for changes in the distribution of power within the international order.

This different approach is based on arguments of a particular type of new institutionalism, whereby normal organizational structures reflect technical demands and resource dependencies, but which are also shaped by institutional forces that include rational myths, knowledge legitimated through the educational system, by the professions, and the law. Organizations are deeply embedded in social and political environments. In addition, these organizational practices and structures also reflect, or are responses to, rules, beliefs, and conventions built into the wider environment. This perspective has a clear sociological flavour that distinguishes it from the remaining ones.

Much of this is also related to the work of Bourdieu $(1977,1980,1984)$ and Bourdieu and Wacquant (1992), which follows a reflexive epistemology and a relational ontology that builds on the notion of 'habitus' and fields. Bourdieu's concept of habitus consists of a system of dispositions that originate in social structures but that are so deeply internalized by actors that they generate behaviour even after the original structural conditions have changed (Swartz, 1997, particularly p. 101). Bourdieu's notions of fields ${ }^{11}$ and symbolic capital deepen our understanding of the network not only as a system of knowledge flows - an instrument or means - but also as an important phenomenon in its own right. The core idea here is that there are processes within organization theory that are pertinent to the realm of international institutions/organizations. These processes may be industrywide, national or international in scope. It can also be considered that this perspective shares common ground with the work of Wendt $(1987,1999)$.

\section{The mechanisms of institutional isomorphism and homogenization}

The central argument of the new sociological institutionalism lies on the processes of institutional homogenization (Lawrence and Suddaby, 2006; Tempel and Walgenbach, 2007). This follows, particularly, from the seminal contribution by Meyer and Rowan (1977) and DiMaggio and Powell (1983). Meyer and Rowan argue that many formal

10 On this subject, see Powell and DiMaggio (1991, specially the introduction).

11 That is, networks or social arenas within which struggles occur for scarce resources. 
organizational structures come about as reflections of rational rules, with institutional rules functioning as myths that organizations incorporate in their structure and mode of operating, thereby also gaining legitimacy and stability. These authors argue that in order to achieve legitimacy, organizations tend to construct stories about their actions and activities. These stories are used as forms of symbolic reassurance to appease influencial people or the public in general. The focus of DiMaggio and Powell (1983) is on processes of institutional homogenization, as well as similarity of practices and arrangements in institutions. In essence, they developed the former theme further. Noting the remarkable similarity of organizations in contemporary industrialized societies, they question why organizations tend to become so similar to each other. Their central argument is that organizations tend to incorporate practices, rules and procedures that have been institutionalized and, in establishing how this process occurs, they highlight coercive, mimetic, and normative processes of reproduction that lead to the isomorphic organizational structures that generate increased legitimacy. Rather than because of competition, or objectives connected to greater efficiency, organizations attempt to obtain legitimacy in their environments in response to institutional pressures. This homogeneity of practices leads to a constant and repetitive modus operandis in organized life that may not be easily explained by a rational-actor approach.

According to DiMaggio and Powell (1983: 150): "Coercive isomorphism results from both formal and informal pressures exerted on organizations by other organizations upon which they are dependent and by cultural expectations in the society within which organizations function". As such, coercive factors may also involve political pressures and the force of the state, and, in some cases, even provide regulatory oversight and control, namely through defining measures and procedures that need to be implemented by the actors within those regulated industries. However, they can also arise from cultural expectations. In the case of international organizations, one can also think of isomorphism resulting from more subtle and indirect processes.

A second source of institutional isomorphism is mimesis (DiMaggio and Powell, 1983: 151). This mechanism works in the sense that actors are pulled towards certain types of organizational models, and often times of work and behaviour, as they find those solutions to be attractive to the problems they face, or favourable in terms of advancement and recognition. This imitation of institutional templates legitimated in the organizations' field often makes up for a lack of rationality of the decision and, last but not least, becomes a saveguard in the case of failure, as one is able to demonstrate having done "what should have been done" or acted "according to correct procedures". This mimetic isomorphism can be seen as a response to uncertainty and as a source of legitimation (DiMaggio and Powell, 1983: 155; Kalev et al, 2006; Meyer and Jepperson, 2000; Meyer and Rowan, 1977; Powell and DiMaggio, 1991).

There is also isomorphism that results from normative factors that stem from the influence of the professions and the role of education, many of them with great authority and influence, as well as mimetic forces drawn on habitual and taken-for-granted responses to circumstances of uncertainty. For instance, universities and other professional training institutions diffuse standards across national boundaries and often become "best practices" in any given profession. As such, they "are important centres for the development of organizational norms among professional managers and their staff" (DiMaggio and Powell, 1983: 152). Moreover, they function as developers of common practices and ways of thinking, thereby favouring professionals in organizations 
at various levels to become alike in background, education and orientation. In many organizations, notably international governmental organizations, there is often an informal filtering in hiring. A similar situation occurs thoughout career progression that also favours isomorphism. In this context, Kontinen and Onali (2017) provide a good example of normative institutional isomorphism involving nongovernmental organizations (NGOs).

The three mechanisms pointed above may not be easy to distinguish from each other empirically. They are separate but can, and most likely do, operate simultaneously, with their results not being easily identifiable. ${ }^{12}$ That issue needs not detain us here. More relevant is the notion that in order to survive, organizations need to convince the environment in which they operate that they are legitimate and that, as a result, they deserve to exist. Organizations have a need to perpetuate these symbolic and ceremonial activities about their activities. They become part of the environment, that is, they become institutionalized. No doubt, international organizations are not immune to these influences, given that their respective bureaucracies also play a determinant role in the way they operate. In addition, some of these processes are also likely to influence political representatives in these organizations and the policies of the single states. The persistence of those practices in these international (governmental) organizations and taken-for-granted ways of proceeding in terms of behaviour and attitudes favours a reproduction of structures that provides additional support to the maintenance of the current international order.

\section{Conclusion}

New institutionalism has become a leading approach within organizational analysis, particularly among north-american organizational sociologists. The main idea is that organizations need to gain legitimacy in order to survive and, as a result, they tend to create myths about themselves, often through symbolic and ceremonial activities. Those become institutionalized and deeply embedded in social and political environments.

We are witnessing power transitions within the international system and it is not yet obvious how this will affect the present international order, not least to what extent. However, despite those power transitions, the fundamental nature of the current international order needs not to change dramatically or, seen from a different perspective, may change at a much slower pace. Many arguments from a liberal institutionalist perspective have argued precisely that. However, in addition to that, the argument presented here is that there are institutional processes and mechanisms that have been studied in organizational theory within the New Institutional Theory that may well provide additional support to the idea of an enduring order. These processes tend to impact organizations in general and irrespective of the area of activity and socio-political context, and, as such, they are likely to influence international organizations as well. The end result may well be that they are likely to play a role in the maintenance of the current

12 For instance, the Asian Infrastructure Investment Bank surely displays elements of isomorphism with the World Bank of both mimetic and normative factors at work, albeit not necessarily easy to identify. This would result from the adoption of similar organizational structures, rules and rituals, as many of the existing features in one organization are present in the other in terms of acting "according to correct and best procedures". 
international order which, consequently, may last longer than is often thought, while accommodating some of the shifts in power that are taking place.

\section{References}

Acharya, A. (2006). Multilateralism, Sovereignty and Normative Change in World Politics. In Edward Newman, Ramesh Thakur and John Tirman (eds.) Multilateralism under Challenge? Power, International Order, and Structural Change. Tokyo: UN University Press.

Archer, C. (2014). International Organizations. London and New York: Routledge.

Barkin, S. (2013). International Organization: Theories and Institutions. New York: Palgrave Macmillan.

Bourdieu, P. (1977). Outline of a Theory of Practice. Cambridge: Cambridge University Press.

Bourdieu, P. (1980). The Logic of Practice. Stanford: Stanford University Press.

Bourdieu, P. (1984). Distinction: A Social Critique of the Judgement of Taste. London: Routledge.

Bourdieu, P. and L. Wacquant. (1992). An Invitation to Reflexive Sociology. Chicago: Chicago University Press.

Campbell, J. (1998). Institutional Analysis and the Role of Ideas in Political Economy, Theory and Society, 27, 3: 377-409.

Christensen, T. J. (2011). The Advantages of an Assertive China: Responding to Beijing's Abrasive Diplomacy. Foreign Affairs, Vol. 90, 2 (March/April): 54-67.

Cortell, A. and Davis, J. (1996). How Do International Institutions Matter? The Domestic Impact of International Rules and Norms. International Studies Quarterly, Vol. 40, 4: 451-478.

DiMaggio, P. J. and Walter W. Powell. (1983). The iron cage revisited: Institutional isomorphism and collective rationality in organizational fields. American Sociological Review, 48, 2: 147-160.

Finnemore, M. (1996). National Interests in International Society. Ithaca and London: Cornell University Press.

Finnemore, M. and Sikkink, K. (1998). International Norm Dynamics and Political Change. International Organization, 52:4 (Autumn): 887-917.

Franck, T. (1990). The Power of Legitimacy among Nations. Oxford: Oxford University Press.

Glanville, L. (2016). Does R2P matter? Interpreting the impact of a norm. Cooperation and Conflict, Vol. 51(2): 184-199.

Haas, P. (1992). Introduction. Epistemic Communities and International Policy Coordination. International Organization, 46, 1: 1-35.

Ikenberry, G. J. (1998/99). Institutions, Strategic Restraint, and the Durability of Western Order. International Security, 23, 3 (winter 1998/99): 43-78. 


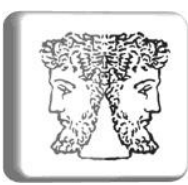

Ikenberry, G. J. (2001). After Victory: Institutions, Strategic Restraint, and the Rebuilding of Order after Major War. Princeton: Princeton University Press.

Ikenberry, G. J. (2009). Liberal Institutionalism 3.0: America and the Dilemmas of Liberal World Order. Perspectives on Politics, Vol. 7, No. 1: 71-87.

Ikenberry, G. J. (2011). Liberal Leviathan: The Origins, Crisis, and the Transformation of the American World Order. Princeton: Princeton University Press.

Ikenberry, G. J. (2013). The Rise of China, the United States, and the Future of the Liberal International Order. In David Shambaugh (ed.) Tangled Titans. Plymouth, UK: Rowman \& Littlefield, Inc.

Ikenberry, G. J. (2014). The logic or order: Westphalia, liberalism, and the evolution of international order in the modern era. In G. J. Ikenberry (ed.) Power, Order, and Change in World Politics. Cambridge: Cambridge University Press.

Immergut, E. (1998). The Theoretical Core of the New Institutionalism, Politics and Society, 26, 1: 5-34.

Jervis, R. (1982). Security Regimes. International Organization, 36, 2: 357-378.

Kalev, A., Frank Dobbin and Erin Kelly. (2006). Best practices or Best Guesses? Diversity Management and the Remediation of Inequality. American Sociological Review, 71, 2: 589-971.

Katzenstein, P. (1996). The Culture of national Security: Norms and Identity in World Politics. New York: Columbia University Press.

Keohane, R. (1984). After Hegemony. Princeton: Princeton University Press.

Keohane, R. (1988). International Institutions: Two Research Programs. International Studies Quarterly, 32, 4: 379-396.

Kontinen, T. and Onali, A. (2017). Strengthening Institutional Isomorphism in Development NGOs? Program Mechanisms in an Organizational Intervention. Sage Open, Volume: 7 issue 1: 1-14. https://doi.org/10.1177/2158244016688725

Krasner, S. D. (1983). International Regimes. Ithaca: Cornell University Press.

Krasner, S. D. (1988). Sovereignty: An Institutional Perspective. Comparative Political Studies, 21, 1: 66-94.

Kratochwil, F. and John G. Ruggie. (1986). International Organization: A State of the Art on the Art of the State. International Organization, 40, 4: 753-776.

Lawrence, T. B., and Roy Suddaby. (2006). Institutions and institutional work. In Stewart R. Clegg, Cynthia Hardy, Thomas B. Lawrence \& Walter R. Nord (Eds.). Sage Handbook of Organization Studies, 2nd Edition. London: Sage.

Legro, J. (1997). Which Norms Matter? Revisiting the "Failure" of Internationalism. International Organization, 51, 1: 31-64.

Meyer, J. W. and Brian Rowan. (1977). Institutionalized organizations: Formal Structure as Myth and Ceremony. American Journal of Sociology, 83, 2: 340-63.

Meyer, J. W. and Ronald Jepperson. (2000). The 'Actors' of Modern Society: The Cultural Construction of Social Agency. Sociological Theory, 18, 1: 100-20. 
Powell, W. W. and Paul J. DiMaggio. (eds.) (1991) The New Institutionalism in Organizational Analysis. Chicago: Chicago University Press.

Puchala, D. J. and and Raymond F. Hopkins. (1982). International Regimes: Lessons from Inductive Analysis. International Organization, 36, 2: 245-275.

Ruggie, J. G. (1982). International Regimes, Transactions, and Change: Embedded Liberalism in the Post War Economic Order. International Organization, 36, 2: 3779-415.

Shambaugh, D. (2011). Coping with a Conflicted China. The Washington Quarterly, Vol. 34, No. 1: 7-27.

Stein, A. (1982). Coordination and Collaboration: Regimes in an Anarchic World. International Organization, 36, 2: 299-324.

Swartz, D. (1997). Culture and Power: The Sociology of Pierre Bourdieu. Chicago: Chicago University Press.

Swidler, A. (1986). Culture in Action: Symbols in Strategies, American Sociological Review, 51, 2: 273-86.

Tempel, A. and Peter Walgenbach. (2007). Global Standartization of Global Forms and Management Practices? What New Institutionalism and the Business-System Approach Can Learn from Each Other. Journal of Management Studies, 44, 1: 1-24.

Weber, M. (1947). Theory of Social and Economic Organization. New York: Oxford University Press.

Weber, M., Guenther Roth, Ckus Wittich. (eds.) 1978. Economy and Society: An Outline of Interpretative Sociology, vols. I e II. Berkeley: University of California Press.

Wendt, A. (1987). The Agent-Structure Problem in International Relations Theory. International Organization, 41 (3): 335-470.

Wendt, A. (1999). Social Theory of International Politics. Cambridge: Cambridge University Press.

Young, O. (1982). Regime Dynamics: The Rise and Fall of International Regimes. International Organization, 36, 2: 277-297.

Young, O. (1986). International Regimes: Towards a New Theory of Institutions. World Politics, 39, 1: 104-122. 